\title{
ROEBLING'S SIXTH BRIDGE, "NEVERSINK"
}

\author{
BY MALCOLM A. BOOTH
}

$\mathrm{Mr}$. Booth is research associate for the Orange County Community of Museums and Galleries in Goshen, New York.

TOHN A. ROEBLING, immigrant New Jersey industrialist whose papers are filed in the Special Collection Department of Rutgers University Library, is remembered chiefly as the designer of the Brooklyn Bridge in New York City (I 867-I 883). Yet, of the first six structures Roebling built, five were aqueducts to carry canals across streams or rivers, a vital project for the time, if seemingly anachronistic for today's world.

Today, an attempt is being made to reconstruct Roebling's last aqueduct, actually his sixth bridge, as it stood when he completed it in $185 \mathrm{I}$ for the Delaware and Hudson Canal. The reconstructed aqueduct would be part of a proposed educational and recreational historic park under the jurisdiction of the Orange County Park Commission. ${ }^{1}$

The Delaware and Hudson Canal was conceived by Maurice and William Wurts, Philadelphia businessmen, in the early I 820 's as a means to transport anthracite coal from land they owned in northeastern Pennsylvania to the presumed markets in New York City. ${ }^{2}$ Mainly by using engineers "borrowed" from the Erie Canal, the ro8-mile Delaware and Hudson was built from Honesdale, Pennsylvania, to Kingston, New York, between I 825 and I $828 .^{3}$

Many aqueducts were required to carry the original canal across streams, brooks, rivers, and creeks in its I08-mile course, but most of them hardly deserved the name. The aqueduct across the Neversink River at Cuddebackville, New York, was a two-span, 224-foot ${ }^{4}$

1 Times Herald-Record (Middletown, N. Y.), July 2, 1965.

${ }^{2}$ Edwin D. LeRoy, The Delaware and Hudson Canal, A History (Honesdale, Penna.: Wayne County Historical Society, 1950), p. 5.

${ }^{3}$ Ibid., p. 8; and Benjamin Wright, Report of Messrs. Benjamin Wright and J. L. Sullivan, Engineers, Engaged in the Survey of the Route of the Proposed Canal, from the Hudson, to the Head Waters of the Lackawaxen River, Accompanied by Other Documents, $E^{\circ}$. (Philadelphia: John Young, 1824), p. 24.

${ }^{4}$ LeRoy, p. 22. 
stone and wood truss structure designed by John B. Jervis. ${ }^{5}$ The wooden portions had to be replaced from time to time because of weather effects and the constantly fluctuating water level. More important, however, was the damage to the single pier in mid-river caused by the ice floes jarring it each spring. ${ }^{6}$

After some initial difficulties, the company found sufficient markets for coal to make the canal profitable and paid its first dividend on December I, I 832.7 Maintenance problems continued, however, and even the canal banks were not made solid enough to contain a full four-foot head of water until I $839 .^{8}$

The growth in profits convinced the canal managers that a larger canal would increase their prosperity. Between I 842 and I85I, practically every inch of the canal was rebuilt, some parts several times, increasing its annual capacity from 200,000 tons $^{2}$ to $\mathrm{I}, 000,000$ tons, ${ }^{10}$ its depth from four feet to six feet, and the boat loads from 30 tons to 136 tons. ${ }^{11}$ The enlargement program naturally required that the aqueducts also be rebuilt, or they would have become bottlenecks to shipping.

$$
\text { * * * } \quad *
$$

The enlarged aqueducts' designer and builder, John A. Roebling, had been born in Mühlhausen, Thuringia, on June I2, I 806, ${ }^{12}$ the son of Christoph Polycarpus Roebling, a tobacconist, and Friederike Roebling. ${ }^{13}$

Because of his mother's thrift and perseverance as well as his own ambition, John Roebling was able to attend the Royal Polytechnic Institute in Berlin from $\mathrm{I} 823$ to $\mathrm{I} 826 .{ }^{14}$ His graduation thesis was a study of the chain suspension bridge over the Regnitz River at Bamberg, Bavaria; ${ }^{15}$ such bridges were a subject that fascinated

5 John B. Jervis, Plans of Structures on the Delaware and Hudson Canal and Carbondale Railroad (Unpublished manuscript, i 826), Plate 29.

${ }^{6}$ Minutes of the Board of Managers, Delaware and Hudson Canal Company, Jan. 6, 1847 .

7 Delaware and Hudson Company, A Century of Progress, History of the Delaware

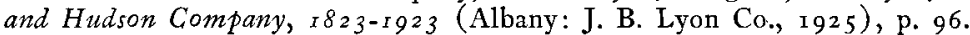

${ }^{8}$ LeRoy, p. 38.

${ }^{10}$ Ibid., p. 129 .

${ }^{9}$ Century of Progress, p. I25.

12 D. B. Steinman, The Builders of the Bridge, the Story of John Roebling and His Son (New York: Harcourt, Brace and Company, 1945), p. 3 .

13 Ibid., p. 4.

${ }^{14}$ Ibid., p. Io.

15 Ibid., p. 14. 
Roebling throughout his life. This early study challenged him to search for engineering principles upon which a safe, dependable suspension bridge could be constructed, a cause in which he succeeded where all of his contemporaries failed. ${ }^{16}$

After working on highways and bridges in Westphalia from I 826 to I 830 , Roebling returned home to Mühlhausen where he participated in the liberal uprisings of I 830 . After the revolts had been repressed, Roebling began preparations to lead a band of immigrants to America. ${ }^{17}$ Despite many disappointments, including separation from the main group of settlers, he helped found a German farming colony at Saxonburg, Pennsylvania, in I $83 \mathrm{I.}^{18}$

Farming was not to Roebling's taste, however, and the years I 837 I 844 were marked by his employment as an engineer on a number of projects, by a wide variety of patent applications, and particularly by his invention of wire rope in $184 \mathrm{I}{ }^{19}$ Three coils of the wire rope were shipped to the Delaware and Hudson Canal Company on May 3r, I 844, apparently for use in hauling their coal cars along the Gravity Railroad from Carbondale to Honesdale, Pennsylvania. ${ }^{20}$

In I 844, Roebling received his first independent construction contract to design and build the seven-span Allegheny canal suspension aqueduct at Pittsburgh. A few weeks before he completed work on this aqueduct, the Monongahela road bridge at Pittsburgh was destroyed, which Roebling was called on to replace with an eightspan suspension bridge, a job he completed in February of I 846.

In that same month, the managers of the Delaware and Hudson Canal Company authorized the construction of aqueducts across the Delaware and Lackawaxen Rivers, ${ }^{21}$ at some places only 600 yards apart. Until this time, the canal boats had been poled across the Delaware, and the mules carried across by a rope ferry. ${ }^{22}$ On December 28 , I 846 , the managers received two plans for each of the aqueducts, one set for wooden structures and the other for wire suspension ones. The two sets of plans were referred to a company committee. ${ }^{23}$

${ }^{16}$ Ibid.

17 Steinman, p. 2 I.

18 Ibid., p. 38.

19 Ibid., p. 66.

${ }^{20}$ John A. Roebling to H. Devine, May 3I, I 844.

${ }^{21}$ Century of Progress, p. I 39.

${ }^{22}$ LeRoy, p. 5 I.

${ }^{23}$ Minutes, Dec. 28, I 846 . 
The committee on January 6, I 847, reported in favor of the wire suspension aqueduct. Although expressing "much doubt" that the wire would be imperishable, "yet they must submit to the opinions of those who have examined the subject more fully." The main advantage of the wire structure, in their opinion, was that only three piers instead of five would be necessary for the Delaware Aqueduct, giving more room for ice floes in time of flood.

Their recommendation, however, was to take effect only after James Archibald, gravity railroad engineer, or Russel F. Lord, canal engineer, inspected a wire suspension bridge in Pittsburgh built by Roebling. ${ }^{24}$

The matter was held in abeyance during another boating season. Meanwhile, in February of 1847 , Roebling prepared a preliminary estimate for all four canal aqueducts, filling an entire notebook with calculations, specifications, and comments.

He estimated then that a one-span aqueduct across the Neversink would cost $\$ 25,000$, while a two-span structure could be built for $\$ 18,000$, plus $\$ 500$ for building an anchorage on the west face. He concluded that "two spans are decidedly preferable, as there will be a saving of $\$ 6,000$ in the Superstructs and there will be also a saving in the masonry or at least this item will not cost more." ${ }^{25}$

On November I 7, I 847, the managers approved a recommendation from the company president, John Wurts (brother to Maurice and William), to enlarge the canal to a depth of six feet to handle cargoes up to $\mathrm{I} 36$ tons, at a cost of $\$ \mathrm{I}, \mathrm{IO} 5,000 .{ }^{26}$ With this enlargement, the annual capacity of the canal was to be one million tons. ${ }^{27}$

Russel Lord inspected Roebling's Pittsburgh bridge in December of 1847 , making a favorable report, ${ }^{28}$ and work on the first two aqueducts began almost immediately; Roebling completed the masonry for the Delaware Aqueduct in January, 1848. The Delaware and Lackawaxen Aqueducts were first put into use on April 26, I $849 .^{29}$

On December 28, I 847, Roebling submitted three propositions to Russel Lord. One was for a one-span aqueduct at High Falls, while

${ }^{24}$ Minutes, Jan. 6, 1847 .

${ }^{25}$ John A. Roebling, "The Delaware and Hudson Aquaducts" (Manuscript notebook, February, ז 847 ), unpaged.

${ }^{26}$ Minutes, Nov. I 7, I 847 .

${ }^{28}$ LeRoy, p. 5 o.

${ }^{27}$ Century of Progress, p. 129.

${ }^{29}$ Ibid., p. $5 \mathbf{1}$. 
for Neversink, he offered a choice between a I 7O-foot, one-span structure with cables of $95 / 8$ inches for $\$ 24,000$, and a i $80-$ foot, twospan structure with cables of $63 / 4$ inches for $\$$ I 8,000 . In either case, all the stonework and rock excavation were to be done by the company, and Roebling was to do all the wood and iron work. ${ }^{30}$

While working on the Delaware Aqueduct, Roebling took time out to purchase 25 acres at Trenton, New Jersey, in August, I 848, for construction of a new wire-rope plant, which supplied the essential bridge cables. ${ }^{31}$ He supervised the plant construction from afar by means of detailed daily letters to the plant manager, Charles Swan.

It is not known why or when the Delaware \& Hudson Company made its decision for a one-span structure at Neversink, but when Roebling prepared a more detailed estimate for the Neversink and High Falls structures in October of 1848 , he mentioned that the company had chosen the one-span proposal.

This time, he came to a price of $\$ 24,900$ for the Neversink Aqueduct, adding at a later time $\$ 230.40$ for 3,840 pounds of tension rods and screws, for a total of $\$ 25, \mathrm{r} 30.40$.

His breakdown of expenses is 44,600 pounds of anchor chains and pins, $\$ 4,460 ; 35,200$ pounds of castings, $\$$ I, 408 ; IO, I 50 pounds of wrought iron, suspenders, etc., $\$ 700 ; 37$ casks of spikes, $\$ 185$; 70,000 pounds of number nine wire for the cables, $\$ 7,000 ; 84,000$ feet board measure of oak timber for the anchorage, $\$ I, 260 ; 1,600$ feet board measure of oak timber for the trunk, $\$ 32 ; 59,000$ feet board measure of white pine timber for the trunk, $\$ 1,062 ; 60,000$ feet board measure of white pine plank, $\$ \mathrm{I}, 080 ; 30,000$ feet board measure of hemlock for the extensions, $\$ 300 ; 292$ feet of caulking, $\$ 300$; tarring and painting, \$100; laying down the anchorage, $\$ 300$; I 50,600 feet of timber and plank to frame and put up, including all expenses, $\$ 2,000$; freight and extras, $\$ 500$; and unspecified, $\$ 3,623$.

He added another note that the Napanoch Iron Works had offered to make the chains used in the anchorage at seven cents a pound, and the pins at six cents.

The actual orders for lumber are remarkably close to the estimate,

\footnotetext{
${ }^{30}$ John A. Rocbling, "The Delawarc and Hudson Aquaducts" (Manuscript notebook, February, I 847), unpaged.

${ }^{31}$ Steinman, p. 136.
} 
and they show that Roebling underestimated only for the oak timber to be used in the trunk.

Dimensions given in his notebook are: span from center to center, I 70 feet; pyramids, two feet higher than those on the Delaware Aqueduct; bottom of the saddle above the canal bottom, I 4 feet, seven inches; point of intersection above the canal bottom, I 4 feet, IO $1 / 2$ inches; camber, I I inches; cables above beams at the center, three and a half inches; cables below bottom at the center, one and a half inches; lowest point of cables above canal bottom, nine and a half inches; deflection of cables, 14 feet, one inch.

He also noted on October 25, I 848, that the company had decided on a single span of I 60 feet between the abutments, or I 70 feet from center to center. The dimensions of the trunk were to be the same as those of the Delaware Aqueduct, I 7 feet, six inches wide at the bottom, 20 feet wide at the top, and nine feet deep. The water surface would be 19 feet, one inch wide, but Roebling continually disagreed with himself over whether the depth of the water in the trunk should be six feet or six feet, six inches. The surface of the Neversink River at low water, he wrote, would be 2 I feet below the bottom of the aqueduct. $^{32}$

Both notebooks carry detailed instructions on how the construction was to be carried out. One sample will suffice:

To avoid the corroding effect of the tanning and galling stuff, contained in Oak, the first course of plank upon the anchorplates, should be of maple wood or any other hard wood, which is free of corroding substances. Pine is too soft. Tarring the plank is also good. A layer of cement is also necessary between the plank and the iron. Avoid all contact of iron and oak timber. Lime is the best preventive. Limewater poured around the screens of the suspension blocks. The seat of the suspension plates should be well tarred, before the plate is put on.- Mallet says, that iron oxid $[s i c]$ in contact with iron, facilitates corrosion. If so, what effect has Spanish Brown, when the oil disappears." ${ }^{33}$

The canal company managers authorized the construction of the new High Falls and Neversink Aqueducts on December 2, $18480^{34}$

32 John A. Roebling, "The Neversink and High Falls Aquaducts" (Manuscript notebook, October, 1848 ), unpaged.

${ }^{33}$ John A. Roebling, "The Delaware and Hudson Aquaducts" (Manuscript notebook, February, I 847 ), unpaged.

${ }^{34}$ Minutes, Dec. 2, 1848 . 
The chief innovation on the Delaware River aqueduct had been that it was the first one to use wire rope instead of wrought iron for the suspension hangers. The aqueduct at Neversink is of importance because it used the largest cables, nine and a half inches in diameter, yet constructed. $^{35}$

Roebling's own comment on the importance of the Neversink Aqueduct is contained in the concluding paragraph of a letter to the American Railroad Journal, printed on January I 3, 1849, in which he also describes progress on the Delaware and Lackawaxen structures. He says:

I have contracted with the company, for two more aquaducts [sic], one over the Roundout [sic] river, the other over the Sink [sic] river, of I 70 feet span, requiring cables of $9 \frac{1}{2}$ inches diameter, large enough for the support of a suspension bridge over the Niagara river, at the site in contemplation below the falls, of 750 feet span. ${ }^{36}$

In order to keep the canal in operation while construction was proceeding, the aqueducts were slightly relocated. Roebling built the Neversink aqueduct about Ioo feet downstream and at more of an angle than the original two-span wood and stone aqueduct. ${ }^{37}$ The relocation required some work on the approaches. It is unknown who the contractor at Neversink was, but the contractor for the more extensive relocation at High Falls was Story, King, and Fuller. ${ }^{38}$

On April 2 I, I 849, Roebling, writing from Two River, Pike County, Pennsylvania, told Swan that "In the course of another Week I shall go down to the High Falls to commence a new Aquaduct." ${ }^{39}$ His first letter to Swan mailed from High Falls was dated May I 9, I 849. ${ }^{40}$

Roebling made High Falls his headquarters for most of the construction period for the last two aqueducts, delegating supervision of the Neversink Aqueduct to David S. Rhule, a Roebling employee

${ }^{35}$ Steinman, pp. I04-105.

${ }^{36} \mathrm{~J}$. A. Roebling, "Suspension Aquaduct on the Delaware and Hudson Canal," American Railroad Journal, 22 (Jan, I 3, I 849), 21-22. Actually, four ten-inch cables were used for the Niagara railroad bridge.

${ }^{37}$ L. W. Weston, Delaware and Hudson Canal maps (surveyed i 854, drawn i 856 , revised in $186_{5}$ by R. F. Lord, Jr.), filmed for the Onondaga Historical Association, Syracuse, New York, by the Delaware and Hudson Railroad Company in October, 1959, Plate XXXVIII.

${ }_{38}$ Minutes, May 20, $\times 850$.

39 John A. Roebling to Charles Swan, April 2 I, 1849.

40 John A. Roebling to Charles Swan, May 19, I 849 . 
from I 845 until at least I $862 .{ }^{41}$ Roebling himself was at Neversink on September 4, I 849, September 20, I849, December 5, I849, and for an extended period late in January, I $85 \mathbf{I}^{42}$

Among his correspondence to Swan in Trenton is a note on August 20, I 849, that "Mr. Rhule got the Anchorage in at the Never Sink A: safe." ${ }^{43}$ For some reason, Roebling decided to put in the second anchorage himself, telling Swan on September 3, I 849, "Tomorrow I have to go up to the Never Sink to lay the second Anchorage."

Probably one of Roebling's more unpopular construction rules was a strict prohibition against smoking "upstairs amongst bedding" in all his projects. The tobacconist's son laid down the rule on September I 7, I 849, after Carl Lange (a common laborer, rough carpenter, and wagon maker) nearly burnt down a construction shanty at High Falls. Another shanty at High Falls had burned down the previous winter, with a loss of three lives. ${ }^{45}$

Roebling recorded the payment of $\$ 8$ on September 6 , 1850 , to W. C. Rose, the district canal superintendent for the Neversink section, for hauling freight at "Codderbackville" [ sic]. He also paid $\$ 90$ on November 29, I 850 , to the Merchants and Tanners line for transporting 2 I unspecified items from "N. S. A." (Neversink Aqueduct) to New York City. ${ }^{46}$

The aqueduct was nearly finished when Roebling, in Cuddebackville, wrote to Swan on January I4, I85r, "We shall commence screwing up to morrow and get through this week. Perhaps I may leave here next Sunday or Monday." ${ }^{47}$

On January 20 , I 85 I, he recorded payment of $\$ 48$ to D. S. Rhule for his expenses in going to Neversink, and also recorded his own travelling expenses of $\$ 16$. On January 30 , I 851 , he noted the receipt of $\$ 64$ from Russel Lord to reimburse him for both expense accounts. ${ }^{48}$

Roebling participated actively in the communities in which he worked. He once wrote Swan that he could not agree to Mrs. Roeb-

${ }^{41}$ Steinman, p. 255.

${ }^{42}$ John A. Roebling to Charles Swan, correspondence (I 849-I 85 I); Roebling account book ( 185 I ).

43 John A. Roebling to Charles Swan, August 20, I 849.

${ }^{44}$ John A. Roebling to Charles Swan, September 3, I 849 .

45 John A. Roebling to Charles Swan, Sept. 18, 1849 .

46 Roebling account book ( 1850 ).

47 John A. Roebling to Charles Swan, Jan. I4, 185 r.

48 Roebling account book (1 851 ). 
ling's wishes that he come home because he was a member of the Board of Health where he was working on the Niagara railroad bridge. ${ }^{49} \mathrm{He}$ also was finicky on matters of address. Another letter to Swan instructs that letters be addressed to "John A. Roebling, Esq., Civil Engineer," not "Mr. J. A. Roebling, Esq., Civil Engineer." ${ }^{50}$

After completing the Neversink Aqueduct, Roebling went on to build bigger and better bridges, introducing new structural materials or techniques in each of them. These later bridges, for which he is best remembered, are the Niagara Railroad Bridge, the PittsburghAllegheny Bridge, the Cincinnati-Covington Bridge, and the Brooklyn Bridge. A fall while doing preliminary surveying for the Brooklyn Bridge led to the death of the great bridge-builder on July 22, I 869, ${ }^{51}$ and the span was completed by his son, Col. Washington A. Roebling.

The four Delaware and Hudson aqueducts continued to give dependable service until the canal was forced by competition from railroads to close in $\mathrm{I} 898 .^{52}$ There had been a proposal to double the size of the Neversink Aqueduct, which was still the bottleneck of the canal despite the enlargement, in $1863,{ }^{53}$ but the decline in canal business after the Civil War led to the abandonment of the idea. ${ }^{54}$

The Neversink and Lackawaxen Aqueducts were dismantled at some undetermined date. The one at High Falls was taken down in I $928 .^{55}$ The Delaware Aqueduct at Minisink Ford, New York, was converted into a toll highway bridge, and now serves modern automobile traffic.

${ }^{49} \mathrm{John}$ A. Roebling to Charles Swan, July 29, I 852.

50 John A. Roebling to Charles Swan, Aug. I $8,1852$.

51 Steinman, p. 320.

${ }^{52}$ Century of Progress, pp. 31 3-3 I 5.

${ }^{53}$ Ibid., p. I 84.

${ }^{54}$ Sullivan County Civil War Centennial Commission, Brass Buttons and Leather Boots (South Fallsburg, New York: Sullivan County Civil War Centennial Commission, I 963$)$, p. 6 I.

${ }_{55}^{5}$ H. C. Boynton, "Bridge Wire Tested After 75 Years," The Iron Age, 121 ( 1928), 400 . 